\title{
Heat Balance Analysis in Cement Rotary Kiln
}

\author{
Shihab Ali Khalifa, Doha Yahia Alsadig \\ Nile Cement Company Ltd, Rabak, Sudan \\ Email address: \\ shihab39ali@gmail.com (S. A. Khalifa), vearachem@gmail.com (D. Y. Alsadig)
}

\section{To cite this article:}

Shihab Ali Khalifa, Doha Yahia Alsadig. Heat Balance Analysis in Cement Rotary Kiln. Advances in Applied Sciences. Vol. 4, No. 2, 2019, pp. 26-32. doi: 10.11648/j.aas.20190402.11

Received: October 7, 2018; Accepted: December 3, 2018; Published: May 26, 2019

\begin{abstract}
The purpose of this study is optimizing the air and fuel quantities at kiln considering design parameters of the cement plant by keeping adequate safety factors at each level of calculations to assure that neither production rate nor quality of the clinker vary. Analysis of Heat balance was used to determine the sources of heat loss from the kiln system. Based on the collected data, an energy balance is applied to the kiln system. The physical properties and equations can be found in Perry's handbook. The reference enthalpy is considered to be zero at $0^{\circ} \mathrm{C}$ for the calculations. The kiln has a capacity of 1000 tonclinker per day. It found that the major heat loss is Heat losses by the kiln exhaust gas (2.33\%), hot air from the cooler stack (7.28\%), Radiation from kiln surfaces $(11.71 \%)$. Some possible ways to recover the heat losses are introduced and discussed and they are Electricity generation, Heat recovery from kiln surface and Pre-heating raw material before the clinkering process.
\end{abstract}

Keywords: Rotary Kiln, Design Parameters, Exhaust Gas, Radiation

\section{Introduction}

Heat balance on a kiln can offer extremely useful information on the thermal performance of the system [1]. Heat balance show where or how the fuel heat is consumed based on the simple principle of input $=$ output $[2,3]$. Unnecessary energy losses can be easily detected, the principle of heat balance may be easily transferred to another system such as preheater, cooler, and drying system. Therefore the use of this study can be extended to another system than cement kiln [3].

Various reasons or circumstances may cause a need for a heat balance measurement. The following situations may justify a heat balance:

1. Performance test,

2. Recoding of kiln performance before/after a modification,

3. Unusually high heat consumption or abnormal kiln operational data,

4. Kiln optimization campaign.

Although the specific heat consumption proper could also be determine by measuring nothing but fuel heat and clinker production, a complete heat balance does offer to considerably more information and security [5]. The consistency of the measured data is proved much better, and the balance shows clearly where the heat is consumed. A heat balance is obviously a very efficient tool assessment of thermal efficiency [6].

A heat balance does not only mean calculation of heat balance items. The complete procedure usually includes the following steps:

\subsection{Preparation}

The extent of works to be done depends on the completeness and reliability which is desired. A careful planning and preparation are recommendable. The following basic items must be clarified:

1. What has to be measured (kiln and location of measuring/sampling points).

2. Duration of test?

3. The frequency of measurements (continuous recording, spot measurements, time intervals, etc)?

4. Necessary log sheets for manual recording ready?

5. Data recording system (electronic, pen recorder etc) available?

6. The flow of information among the test team?

7. Calibration and checks of instruments and scales done (flowmeters, orifice plates, ventures,do-cell, thermocouples, etc.?

8. Temporary measuring equipment available? Complete? 
Correct span? Functioning properly?

9. For example:

a. Pitot tube

b. U-tube manometer

c. Mobile thermometer

d. Radiation pyrometer

e. Orsat / gas analyzer

f. Sampling equipment for gas

g. Sampling procedure for solids (e.g meal, dust, clinker) clarified?

\subsection{Execution}

An important precondition for a good test is steady kiln operation. The test should only be started if the system has reached a constant equilibrium state. During the test, variations of operating parameters should be avoided. For the measuring techniques, reference is made to the corresponding paper.

It is recommended to check completeness and reliability of measurements already during the test, afterward missing or uncertain information may create problems at the final evaluation.

\subsection{Evaluation}

This step is the scope of this paper. Evaluation of data means to establish a heat balance calculation according to the principle "input $=$ output"

\subsection{Discussion}

A heat balance is such must bring some practical conclusions otherwise it would be only of academically interest. The following items may be considered:

1. Acceptable (normal) heat consumption?

2. Are heat balance items normal for given kiln system?

3. Measures in order to improve the heat economy of the system?

The last item can become quite an extensive work and the economic feasibility must be considered as well. Such subject, however, is beyond the scope of this paper. Summarizing, it is obvious that the $3^{\text {rd }}$ step "evaluation" is only a limited part in the whole context [7].

\section{Methods of Testing Calculations}

\subsection{Assumptions}

In order to analyze the rotary kiln thermodynamically, the following assumptions are made:

1. The system is assumed to be steady state, steady flow \& open.

2. Kinetic \& Potential energy changes of input and output materials are negligible.

3. Ambient conditions are constant throughout the study i.e. $\mathrm{T} 0=301 \mathrm{~K}$.

4. Raw material and coal material composition do not change \& feed rate of both are constant.

5. The natural convection is taken into account as the velocity of atmospheric air is $<3 \mathrm{~m} / \mathrm{s}$.

6. Average kiln surface temperature does not change throughout the study.

7. The gases inside the kiln are assumed to be ideal gases.

Table 1. Equations used to calculate the rotary kiln Heat balance.

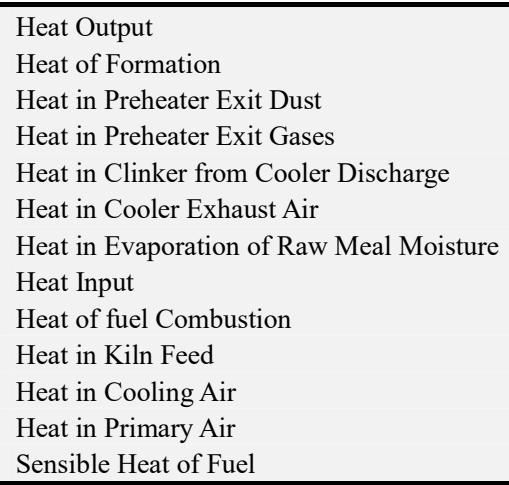

\subsection{Basic data}

\subsubsection{Kiln Dimensions}

Diameter (m):

Length $(\mathrm{m})$ :

\subsubsection{Preheater4Stage Cyclone with Calciner}

Feed temperature $\left({ }^{\circ} \mathrm{C}\right)$ :

Raw Meal Feed rate (tph):

Raw Meal Moisture (\%):

Gas after preheater $\left({ }^{\circ} \mathrm{C}\right)$ :

Orsat measurements :

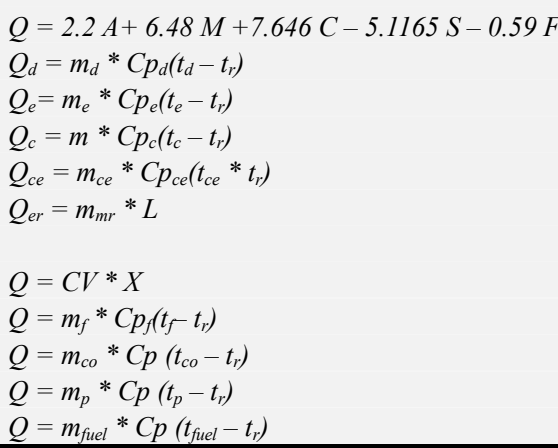

\section{$\mathrm{O}_{2}(\%): \quad 3.5$}

$\mathrm{CO}(\%): \quad 0.01$

Dust from cyclones (ton/hour):

Pitot measurements, $\mathrm{kg} / \mathrm{sec}$ : 24.94

\subsubsection{Firing System}

i. Fuel: Gasoline

Calorific value ( $\mathrm{kcal} / \mathrm{kg})$ :

ii. Kiln primary air

Temperature $\left({ }^{\circ} \mathrm{C}\right)$ :

Pitot measurements ( $\mathrm{kg}$ air/kg clinker): 
iii. Calciner primary air

Temperature $\left({ }^{\circ} \mathrm{C}\right)$ :

Flow rate (kg air/kg clinker):

40

0.009

\subsubsection{Grate Cooler}

i. Exhaust air:

Temperature $\left({ }^{\circ} \mathrm{C}\right)$ :

Pitot measurements (kg air/sec):

ii. Clinker from cooler

Temperature $\left({ }^{\circ} \mathrm{C}\right)$

iii. Cooling air

Flow rate, $\mathrm{kg} / \mathrm{kg}$ clinker:

2.4

Temperature $\left({ }^{\circ} \mathrm{C}\right)$ :

\subsection{Analysis of Clinker}

Table 2. The chemical composition of clinker sample.

\begin{tabular}{ll}
\hline Component & Percentage\% \\
\hline $\mathrm{CaO}$ & 64.40 \\
$\mathrm{SiO}_{2}$ & 21.46 \\
$\mathrm{Al}_{2} \mathrm{O}_{3}$ & 04.85 \\
$\mathrm{Fe}_{2} \mathrm{O}_{3}$ & 04.79 \\
$\mathrm{MgO}$ & 03.63 \\
$\mathrm{SO}$ & 00.50 \\
$\mathrm{~L} . \mathrm{O} . \mathrm{I}$ & 00.79 \\
$\mathrm{~K}_{2} \mathrm{O}$ & 00.50 \\
$\mathrm{Na}_{2} \mathrm{O}$ & 00.26 \\
\hline
\end{tabular}

Mean specific heats between 0 and $\mathrm{T}^{\circ} \mathrm{C}$

$C p=A+B * T * 10^{-6}+C * T 2 * 10^{-9} \mathrm{kcal} / \mathrm{kg} .{ }^{\circ} \mathrm{C}$

Table 3. Values of coefficients.

\begin{tabular}{llll}
\hline Component & A & B & C \\
\hline $\mathrm{CO}_{2}$ & 0.196 & 118 & -43 \\
$\mathrm{H}_{2} \mathrm{O}$ & 0.443 & 39 & 28 \\
$\mathrm{~N}_{2}$ & 0.244 & 22 & 0 \\
$\mathrm{O}_{2}$ & 0.218 & 30 & 0 \\
Air & 0.237 & 23 & 0 \\
Raw Meal & 0.206 & 101 & -37 \\
Clinker & 0.186 & 54 & 0 \\
Coal & 0.262 & 390 & 0 \\
\hline
\end{tabular}

Table 4. Heat for evaporation of water: $\mathrm{kcal} / \mathrm{kg}$.

\begin{tabular}{llll}
\hline Temp. ${ }^{\circ} \mathbf{C}$ & $\mathbf{0}$ & $\mathbf{2 0}$ & $\mathbf{1 0 0}$ \\
\hline Heat Evaporationkcal $/ \mathrm{kg}$ & 597 & 586 & 539 \\
\hline
\end{tabular}

\section{Results}

\subsection{Basis}

1. $1 \mathrm{~kg}$ of clinker

2. Reference Temperature $0^{\circ} \mathrm{C}$

\subsection{Heat Outputs}

\subsubsection{Heat of Formation}

Considering loss free clinker as loss-free meal feedstock under equilibrium condition

Loss-free feedstock composition:
$\mathrm{SiO}_{2}=21.46 \%$

$\mathrm{Al}_{2} \mathrm{O}_{3}=4.85 \%$

$\mathrm{Fe}_{2} \mathrm{O}_{3}=4.79 \%$

$\mathrm{CaO}=64.4 \%$

$\mathrm{MgO}=3.63 \%$

$Q=2.2 A+6.48 M+7.646 C-5.1165 S-0.59 F$

$\mathrm{Q}=2.2 * 4.85+6.48 * 3.63+7.646 * 64.45 .1165 * 21.46-$

$0.59 * 4.79$

$\mathrm{Q}=413.75 \mathrm{kcal} / \mathrm{kg}$ clinker

\subsubsection{Heat in Preheater Exist Dust}

1. Gross dust loss $=8.5 \mathrm{tph}$

2. Clinker output rate $=42 \mathrm{tph}$

Dust in Preheater Exit Gas $=12 / 1000$

$=0.24 \mathrm{~kg}$ dust $/ \mathrm{kg}$ clinker

Mean Specific heat:

$C p_{d}=A+B \cdot T \cdot 10^{-6}+C \cdot T^{2} \cdot 10^{-9} \mathrm{kcal} / \mathrm{kg}^{\circ} \mathrm{C}$

From table 3:

$\mathrm{A}=0.206, \mathrm{~B}=101, \mathrm{C}=-37$

Therefore:

$\mathrm{Cp}_{\mathrm{d}}=0.2305 \mathrm{kcal} / \mathrm{kg}^{\circ} \mathrm{C}$

$\mathrm{t}_{\mathrm{d}}=330^{\circ} \mathrm{C}$

$\mathrm{t}_{\mathrm{r}}=0^{\circ} \mathrm{C}$

$Q_{d}=m_{d} * C p_{d} *\left(t_{d}-t_{r}\right)$

$\mathrm{Q}_{\mathrm{d}}=0.24 * 0.2305(330-0)$

$=18.25 \mathrm{kcal} / \mathrm{kg}$ clinker

\subsubsection{Heat in Preheater Exist Gases}

$Q_{e}=m_{e}{ }^{*} C p_{e}^{*}\left(t_{e}-t_{r}\right)$

Pitot measurements of kiln exit gases $=24.94 \mathrm{~kg} / \mathrm{sec}$

Clinker Production $=1000 \mathrm{tpd}$

$\mathrm{m}_{\mathrm{e}}=24.94 / 11.6$

$$
=11.6 \mathrm{~kg} / \mathrm{sec}
$$

$$
=2.15 \mathrm{~kg} / \mathrm{kg} \text { clinker }
$$

Exit gas composition:

$\mathrm{O}_{2}=2.8 \%$

$\mathrm{CO}_{2}=26.3 \%$

$\mathrm{CO}=0.03 \%$

Assuming balance gases as $\mathrm{N}_{2}$

$\mathrm{N}_{2}=70.87 \%$

Table 5. Determination of gases weight fraction.

\begin{tabular}{llll}
\hline Gas & vol.fraction & WT.fraction & WT.\% \\
\hline $\mathrm{O}_{2}$ & 0.028 & $0.028 * 32 / 22.4=0.04$ & 2.77 \\
$\mathrm{CO}_{2}$ & 0.263 & $0.263 * 44 / 22.4=0.516$ & 35.77 \\
$\mathrm{CO}$ & 0.0003 & $0.0003 * 28 / 22.4=0.000375$ & 0.026 \\
$\mathrm{~N}_{2}$ & 0.7087 & $0.7087 * 28 / 22.4=0.8859$ & 61.434 \\
Total & 1.0 & 1.4422 & \\
\hline
\end{tabular}

The specific heat of exist gas is the sum of specific heats of individual gas composition. Considering that waste gases in terms of weight percentage comprise of $2.77 \% \mathrm{O}_{2}, 35.77 \%$ $\mathrm{CO}_{2}$ and $61.46 \% \mathrm{~N}_{2}$.

$\mathrm{Cp}_{\mathrm{e}}=(2.77 / 100)\left(0.218+30 * 269 * 10^{-6}\right)+$ $(35.77 / 100)\left(0.196+118 * 269 * 10^{-6}\right)-\left(43 * 2692 * 10^{-}\right.$

$\left.{ }^{9}\right)+(61.46 / 100)\left(0.244+22 * 269 * 10^{-6}\right)$

$=0.2402 \mathrm{kcal} / \mathrm{kg}^{\circ} \mathrm{C}$

Heat in preheater exist gas 
$\mathrm{Qe}=2.15 * 0.2402 *(330-0)$

$=170.42 \mathrm{kcal} / \mathrm{kg}$ clinker

\subsubsection{Heat in Clinker from Cooler Discharge}

$Q_{c}=m * C p_{c} *\left(t_{c}-t_{r}\right)$

$\mathrm{m}=$ wt. of clinker

$\mathrm{C} \mathrm{p}_{\mathrm{c}}=$ mean specific heat of clinker, $\mathrm{kcal} / \mathrm{kg}^{\circ} \mathrm{C}$

$\mathrm{t}_{\mathrm{c}}=$ temperature of clinker, $=120^{\circ} \mathrm{C}$

$\mathrm{C} \mathrm{p}_{\mathrm{c}}=0.186+54 * 140 * 10^{-6}$

$=0.1935 \mathrm{kcal} / \mathrm{kg}^{\circ} \mathrm{C}$

$\mathrm{Q}_{\mathrm{c}}=1 * 0.1935 *(140-0)$

$=27.1 \mathrm{kcal} / \mathrm{kg}$ clinker

\subsubsection{Heat in Cooler Exhaust Air}

$Q_{c e}=m_{c e} * C p_{c e} *\left(t_{c e}-t_{r}\right)$

Pitot measurement of cooler exhaust air $=11.34 \mathrm{~kg} / \mathrm{sec}$

Clinker output rate $=11.6 \mathrm{~kg} / \mathrm{sec}$

$\mathrm{m}_{\mathrm{ce}}=11.34 / 11.6$

$=0.98 \mathrm{~kg}$ air $/ \mathrm{kg}$ clinker

$\mathrm{t}_{\mathrm{ce}}=340^{\circ} \mathrm{C}$

$\mathrm{Cp}_{\mathrm{ce}}=0.237+23 * 240 * 10^{-6}$

$=0.2425 \mathrm{kcal} / \mathrm{kg}^{\circ} \mathrm{C}$

$\mathrm{Q}_{\mathrm{ce}}=0.98 * 0.2425 * 240$

$=57.041 \mathrm{kcal} / \mathrm{kg}$ clinker

\subsubsection{Heat in Evaporation of Raw Meal Moisture}

$Q_{e r}=m_{m r} * L$

Raw meal feed rate $=70 \mathrm{tph}$

$$
=1.66 \mathrm{~kg} / \mathrm{kg} \text { clinker }
$$

Moisture in Raw Meal $=0.5 \%$

Therefore, wt. of moisture $=1.66 * 0.5 / 100$

$$
=8.3 * 10^{-3} \mathrm{kgwater} / \mathrm{kg} \text { clinker }
$$

Heat of evaporation of moisture $=597 \mathrm{kcal} / \mathrm{kg}$

Therefore, Heat of evaporation of raw meal moisture

$\mathrm{Q}_{\mathrm{er}}=8.3 * 10^{-3} * 597$

$=4.95 \mathrm{kcal} / \mathrm{kg}$ clinker

\subsubsection{Radiation and Conventional Losses}

Kiln $45.7 \mathrm{kcal} / \mathrm{kg}$ clinker

Preheater $40.7 \mathrm{kcal} / \mathrm{kg}$ clinker

Cooler $5.2 \mathrm{kcal} / \mathrm{kg}$ clinker

Total heat loss by radiation and convention:

$\mathrm{Q}=91.6 \mathrm{kcal} / \mathrm{kg}$ clinker

\subsection{Heat Input}

\subsubsection{Heat of Fuel Combustion}

$Q=C V * X$

Where $\mathrm{X}=$ fuel consumption,

$$
=0.118 \mathrm{~kg} \text { fuel } / \mathrm{kg} \text { clinker }
$$

$\mathrm{CV}=8000 \mathrm{kcal} / \mathrm{kg}$

Therefore, Heat of fuel Combustion = $8000 * 0.118=944 \mathrm{kcal} / \mathrm{kg}$ clinker

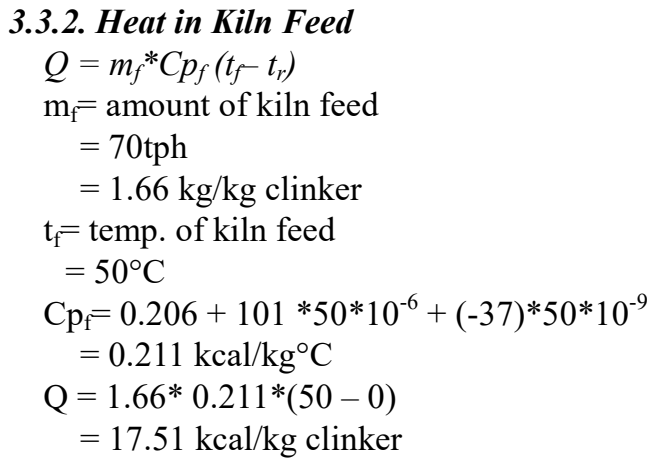

3.3.3. Heat in Cooling Air

$Q=m_{c o}{ }^{*} C p\left(t_{c o}-t_{r}\right)$

$\mathrm{m}_{\mathrm{co}}=$ amount of cooling air

$=27.84 \mathrm{~kg} / \mathrm{sec}=2.4 \mathrm{~kg} / \mathrm{kg}$ clinker

$\mathrm{t}_{\mathrm{co}}=$ temp. of cooling air

$=37^{\circ} \mathrm{C}$

$\mathrm{Cp}$ air at $37^{\circ} \mathrm{C}$

$=0.237+23 * 37^{*} 10^{-6}$

$=0.238 \mathrm{kcal} / \mathrm{kg}^{\circ} \mathrm{C}$

$\mathrm{Q}=2.4^{*} 0.238^{*}(37-0)$

$=21.12 \mathrm{kcal} / \mathrm{kg}$ clinker

\subsubsection{Heat in Primary Air}

$Q=m_{p} * C p\left(t_{p}-t_{r}\right)$

$\mathrm{m}_{\mathrm{p}}=$ total primary air (kiln \&calciner)

Primary air to kiln $=0.073 \mathrm{~kg} / \mathrm{kg}$ clinker

Primary air to Calciner $=0.009 \mathrm{~kg} / \mathrm{kg}$ clinker

$\mathrm{m}_{\mathrm{p}}=$ Total Primary Air

$=0.082 \mathrm{~kg} / \mathrm{kg}$ clinker

$\mathrm{t}_{\mathrm{p}}=$ Temperature of Primary air

$=40^{\circ} \mathrm{C}$

$\mathrm{Cp}=0.237+23 * 40 * 10^{-6}$

$=0.238$

$\mathrm{Q}=0.082 * 0.238 *(40-0)$

$=0.8 \mathrm{kcal} / \mathrm{kg}$ clinker

3.3.5. Sensible Heat of Fuel

$Q=m_{\text {fuel }} * C p\left(t_{\text {fuel }}-t_{r}\right)$

Mean Cp of gasoline $=0.53 \mathrm{kcal} / \mathrm{kg} .{ }^{\circ} \mathrm{C}$

$\mathrm{Q}=0.118 * 0.53 *(55-0)$

$=3.44 \mathrm{kcal} / \mathrm{kg}$ clinker

\subsection{Total Heat Inputs and Outputs}

Total Heat Inputs $=986.87 \mathrm{kcal} / \mathrm{kg}$ clinker Total Heat Outputs $=783.11 \mathrm{kcal} / \mathrm{kg}$ clinker Calculation of Heat loss Total Heat Input $=$ Total Heat Output

Heat loss $=986.87-783.11$ $=203.76 \mathrm{kcal} / \mathrm{kg}$ clinker 


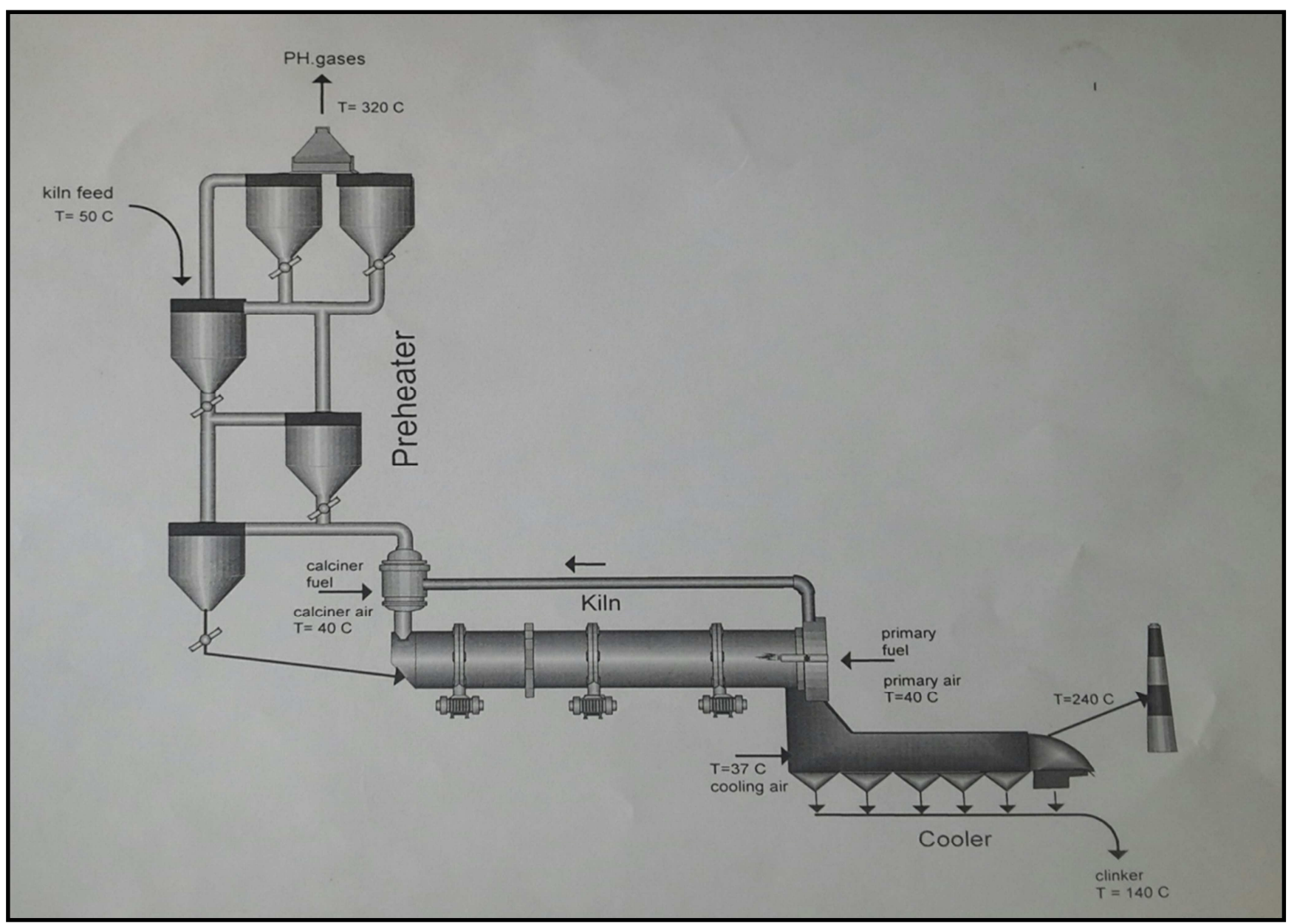

Figure 1. Flow diagram show the kiln and preheater system.

Heat balance of kiln

Clinker output: 1000tpd

Table 6. Summary of total heat balance of kiln.

\begin{tabular}{lll}
\hline Items & Kcal/kg clinker & Percentage\% \\
\hline Heat input & & 95.66 \\
Heat through fuel combustion & 944 & 1.77 \\
Sensible heat in kiln feed & 17.51 & 0.35 \\
Sensible heat in fuel & 3.44 & 2.22 \\
Sensible heat in air (cooling air and primary air) & 21.92 & 100 \\
Total heat input & 986.87 & 21.76 \\
Heat output & & 2.33 \\
Heat in ph exit gases & 170.42 & 52.83 \\
Heat in dust in ph exit gases & 18.25 & 7.28 \\
Theoretical heat of reaction & 413.75 & 3.46 \\
Heat in cooler exhaust air & 57.04 & 0.63 \\
Heat in clinker leaving cooler & 27.1 & \\
Heat in evaporation of moisture rawmeal & 4.95 & 11.71 \\
Radiation and convection losses & & \\
1. kiln45.7kcal/kg clinker & 91.6 & 100 \\
2. preheater40.7kcal/kg clinker & & \\
3. cooler5.2kcal/kg clinker & 783.11 & \\
Total heat output & & \\
\hline
\end{tabular}

Net specific heat of fuel combustion $=1000 \mathrm{kcal} / \mathrm{kg}$ clinker

\section{Discussion}

Based on the collected data, an energy balance is applied to the kiln system. The reference enthalpy is considered to be zero at $0^{\circ} \mathrm{C}$ for the calculations. The complete energy balance for the system is shown in Table 6. It is clear that the total 
energy used in the process is $986.87 \mathrm{~kJ} / \mathrm{kg}$-clinker, and the main heat source is Gasoline, giving a total heat of 944 $\mathrm{kJ} / \mathrm{kg}$-clinker $(95.66 \%)$.Also, the energy balance given in Table 6 indicates relatively good consistency between the total heat input and total heat output. Since most of the heat loss sources have been considered, there is only a $203 \mathrm{~kJ} / \mathrm{kg}$ clinker of energy difference from the input heat. This difference is nearly $20 \%$ of the total input energy and can be attributed to the assumptions and nature of data. The distribution of heat losses to the individual components exhibits reasonably good agreement with some other key plants reported in the literature.

\subsection{General Remarks}

1. It was found that the gases out at a high temperature of $330^{\circ} \mathrm{C}$ caused damage in the filter bags.

2. Radiation affects the performance of workers near the kiln.

\subsection{Heat Recovery from the Kiln System}

The overall system efficiency can be defined by $\eta$ $=\mathrm{Q}_{6} / \mathrm{Q}_{\text {totalinput }}, \eta=413.75 / 986.87=0.42$ or $42 \%$, which can be regarded as relatively low. Some kiln systems operating at full capacity would declare an efficiency of $55 \%$ based on the current dry process methodology. The overall efficiency of the kiln system can be improved by recovering some of the heat losses [9]. The recovered heat energy can then be used for several purposes, such as electricity generation and preparation of hot water. There are a few major heat loss sources that would be considered for heat recovery.

These are heat losses by (1) preheater exhaust gas $(21.76 \%),(2)$ hot air from the cooler stack (7.28\%) and (3) radiation from kiln surfaces $(11.7 \%)$. In the following section, there are some possible ways for recovering this wasted heat energy:

\subsubsection{Electricity Generation}

There are many ways in which heat wasted to the environment is captured and utilized for preheating and electricity generation. One of the most accessible and in turn the most cost-effective heat losses available are the kiln exhausts gas and cooler discharge. The exhaust gas from the kilns is on average, $330^{\circ} \mathrm{C}$, and the temperature of the air discharged from the cooler stack is $240^{\circ} \mathrm{C}$. These streams are directed into the waste heat recovery generator which will convert the available energy into electricity. Thus this, in turn, reduces the electrical demand of the plant $[10,11]$.

\subsubsection{Pre-heating}

Apart from power production, one of the most effective methods of waste heat recovery is to preheat the raw material before the clinkering process. Preheating is usually achieved by directing gas streams into the raw material just before the grinding mill, which helps in increasing the temperature of the raw material and also lead to more efficient grinding process [12].

\subsubsection{Heat Recovery from Kiln Surface}

The hot surface of the kiln is another source of waste heat recovery, in which heat loss occurs by convection and radiation which is about $11.71 \%$ of the input energy. The use of the secondary shell on kiln surface can significantly reduce this loss which will reduce fuel consumption and increase the overall system efficiency by approximately 5-6\% [13].

\section{Conclusions}

A detailed energy audit analysis, which can be directly applied to any dry kiln system, has been made for a specific key cement plant. The distribution of the input heat energy to the system components showed good agreement between the total input and output energy and gave significant sights about the reasons for the low overall system efficiency.

According to the results obtained, the system efficiency is $42 \%$. The major heat loss sources have been determined as preheater exhaust gas $(21.76 \%$ of total input), cooler exhaust (7.28\% of total input) and combined radioactive and convective heat transfer from total kiln surfaces $(11.71 \%$ of total input).

For the first two losses, a conventional West heat recovery steam generation system (WHRSG) system is proposed. For the kiln surface, a secondary shell system has been proposed and designed.

\section{References}

[1] N. A. Madlool, R. Saidur, M. S. Hossain, and N. A. Rahim, "A critical review on energy use and savings in the cement industries," Renew. Sustain. Energy Rev., vol. 15, no. 4, pp. 2042-2060, 2011.

[2] A. Atmaca and R. Yumrutaş, "Analysis of the parameters affecting energy consumption of a rotary kiln in cement industry," Appl. Therm. Eng., vol. 66, no. 1-2, pp. 435-444, 2014.

[3] T. Engin and V. Ari, "Energy auditing and recovery for dry type cement rotary kiln systems - A case study," Energy Convers. Manag., vol. 46, no. 4, pp. 551-562, 2005.

[4] V. Karamarković, M. Marašević, R. Karamarković, and M. Karamarković, Recuperator for waste heat recovery from rotary kilns," Appl. Therm. Eng., vol. 54, no. 2, pp.470-480, 2013.

[5] Z. Söğüt, Z. Oktay, and H. Karakoç, "Mathematical modeling of heat recovery from a rotary kiln," Appl. Therm. Eng., vol. 30, no. 8-9, pp. 817-825, 2010.

[6] L. a. J. \& G. M. A. Ramesh, "Energy Audit of Thermal Utilities in a Cement Plant," Int. J. Mech. Eng., vol. 2, no. 2, pp. 11-22, 2013.

[7] J.-H. Xu, T. Fleiter, W. Eichhammer, and Y. Fan, "Energy consumption and $\mathrm{CO} 2$ emissions in China's cement industry: A perspective from LMDI decomposition analysis," Energy Policy, vol. 50, pp. 821- 832, 2012. 
[8] N. a. Madlool, R. Saidur, N. a. Rahim, and M. Kamalisarvestani, "An overview of energy savings measures for cement industries," Renew. Sustain. Energy Rev., vol.19, pp. 18-29,2013.

[9] D. Song and B. Chen, "A Life Cycle Modeling Framework for Greenhouse Gas Emissions of Cement Industry," Energy Procedia, vol. 61, pp. 2649-2653, 2014.

[10] W. Wang, D. Jiang, D. Chen, Z. Chen, W.Zhou, and B. Zhu, "A MFA-based potential analysis of eco-efficiency indicators of China's cement and cement-based materials industry," J. Clean. Prod., 2015.
[11] A. M. Radwan, "Different Possible Ways for Saving Energy in the Cement Production,"Adv. Appl. Sci. Res., vol. 3, no. 2, pp. 1162-1174, 2012.

[12] J. A. Moya, N. Pardo, and A. Mercier, "The potential for improvements in energy efficiency and $\mathrm{CO}_{2}$ emissions in the EU27 cement industry and the relationship with the capital budgeting decision criteria," J. Clean. Prod., vol. 19, no. 11, pp. 1207-1215, 2011.

[13] Equipment, "Energy auditing in cement industry: A case study," vol. 2, pp. 171- 184, 2014. 